Techniques \& Culture

$4 \mid 1985$

Aspects des agricultures insolites de l'Amérique indienne

\title{
L'écorce battue chez les Anga de Nouvelle-Guinée
}

\section{Pierre Lemonnier}

\section{(2) OpenEdition}

Journals

Édition électronique

URL : https://journals.openedition.org/tc/992

DOI : $10.4000 /$ tc. 992

ISSN : 1952-420X

Éditeur

Éditions de l'EHESS

Édition imprimée

Date de publication : 1 février 1985

ISSN : 0248-6016

Référence électronique

Pierre Lemonnier, «L'écorce battue chez les Anga de Nouvelle-Guinée», Techniques \& Culture [En ligne], 4 | 1985, mis en ligne le 26 janvier 2006, consulté le 29 septembre 2022. URL : http://

journals.openedition.org/tc/992 ; DOI : https://doi.org/10.4000/tc.992

Ce document a été généré automatiquement le 29 septembre 2022.

Tous droits réservés 


\title{
L'écorce battue chez les Anga de Nouvelle-Guinée
}

\author{
Pierre Lemonnier
}

